\title{
Researcher experience as an instrument of investigation of a phenomenon: An example of heuristic research
}

\section{A experiência do pesquisador como instrumento}

na investigação de um fenômeno: um

exemplo de pesquisa heurística

\author{
Elizabeth Brown Vallim BRISOLA \\ Vera Engler CURY ${ }^{1}$
}

\begin{abstract}
Heuristic investigation, one of the lesser-known qualitative research methods in Brazil, is presented as a phenomenological research design in an empirical study investigating the experience of singing. This article describes the six phases of the heuristic method: initial engagement, immersion, incubation, illumination, explication, and creative synthesis. The method was developed by Clark Moustakas (1923-2012), an American clinical psychologist who, together with other renowned scholars such as Carl R. Rogers and Abraham H. Maslow, also contributed to the birth of Humanistic Psychology. The heuristic inquiry is a unique method in which the lived experience of the researcher becomes the main focus of the study, and it is used as an instrument in the process of understanding a given phenomenon. This method recognizes the importance of intuition and tacit knowledge as elements that enable comprehending a phenomenon and its meanings.
\end{abstract}

Keywords: Heuristic research; Phenomenological psychology; Psychological intervention.

\section{Resumo}

O presente artigo objetiva apresentar o método heurístico como um modo fenomenológico de pesquisar a partir de um estudo realizado sobre a experiência de cantar. Descreve as seis fases que devem guiar o pesquisador: engajamento inicial, imersão, incubação, iluminação, explicação e sintese criativa. Clark Moustakas (1923-2012), psicólogo clínico norte-americano que desenvolveu essa estratégia metodológica, contribuiu para o surgimento da Psicologia Humanista, juntamente com expoentes como Carl R. Rogers e Abraham H. Maslow. O método heurístico é singular por valorizar o envolvimento da experiência do pesquisador como instrumento na busca pela compreensão do fenômeno em foco. Reconhece a importância da intuição e do conhecimento tácito como elementos que possibilitam revelar a natureza do fenômeno e seus significados.

Palavras-chave: Pesquisa heurística; Psicologia fenomenológica; Intervenção psicológica.

\footnotetext{
D.

1 Pontifícia Universidade Católica de Campinas, Centro de Ciências da Vida, Programa de Pós-Graduação em Psicologia. Av. John Boyd Dunlop, s/n., Jardim Ipaussurama, 13060-904, Campinas, SP, Brasil. Correspondência para/Correspondence to: V.E. CURY. E-mail: <vency2985@gmail.com>.

Financial support: Coordenação de Aperfeiçoamento de Pessoal de Nível Superior.
} 
There are a variety of research methods available for qualitative researchers to choose from. If the objective is to investigate what Amatuzzi (2010) describes as "human nature, behavior, attitudes, and values from a psychological perspective" or to understand complex phenomena that are difficult to investigate using traditional approaches (Gomes, 2007), there are at least 32 methods of qualitative data collection available (Maddil \& Gough, 2008).

Rennie (2012) classifies qualitative research methods as: "experiential", "discursive", or "experiential/discursive" methods. He describes the "experiential" method as one that involves "the conceptualization of meanings of experiences whether reported by participants or inferred through participant observation. The conceptualizations take the form of either structures, narratives, themes, categories, or combinations of these forms" (p.385). Some examples are: the descriptive phenomenological psychological method, interpretative phenomenological analysis, narrative analysis, the grounded theory method, and heuristic research. Perhaps the lesserknown in Brazil among these methods is heuristic research (Moustakas, 1981, 1990a, 1990b, 1994a, $1995,2001)$. Heuristic research is a phenomenological investigation approach in which the researcher becomes personally involved in the process.

A search conducted in the Scopus (Elsevier) database for articles published in the past five years was conducted using the keywords heuristic research and Moustakas. It revealed 20 international articles (in journals revised by peers) that addressed some aspects of heuristic methodology in the area of human and social sciences. Using the same keywords, 19 international dissertations published after 2009 were identified using the PsycINFO database in the "Dissertation Abstracts International", which shows that, heuristic research has been used in universities around the world. In Brazil, no articles were found using these keywords searching traditional databases such as SciELO and PePSIC. However, a more informal search on Google Scholar revealed one single article in the area of applied linguistics (Vian, 2008), and two articles with a the heuristic method (Holanda, 2006; Sales, Sousa, \& Cavalcante Junior, 2012). In Brazil, there are also some theses and dissertations available in the area of psychology (Brisola, 2000; Maciel, 2004; Vasconcelos, 2009) and academic conference papers (Batista \& Maciel, 2011; Brisola, 2014; Brisola \& Cury, 2013; Maciel, 2011; Santana \& Maciel, 2011; Villar \& Maciel, 2011).

Heuristic investigations have been conducted by researchers in various countries and areas such as clinical psychology, education, anthropology, sociology, and medicine (Blau, Bach, Scott, \& Rubin, 2013), as well as in counseling, art therapy and psychotherapy (Kenny, 2012). The Handbook of Humanistic Psychology: Leading edges in theory, research, and practice, describes pioneer methodologies that challenge "the hegemony of the natural science approach in psychology" (Schneider, Bugental, \& Pierson, 2001, p.241). Why is the heuristic method considered a pioneer? Due to its main focus on the researcher's experience and process of transformation, explicitly acknowledging the researcher involvement to the extent that his/ her experience becomes the main focus of the research (Hiles, 2001). Although other phenomenological methods also value the researcher subjectivity, the heuristic approach puts it, explicitly, in the center of the investigative process. The researcher becomes engaged in a search for patterns and meanings starting from one's own experience with the phenomenon studied; the result is a description of the essential elements of both one's lived experience and those of the participants (Douglass \& Moustakas, 1985).

In qualitative studies, in general, there is a presupposition that the researcher is not neutral. There is "personal commitment even when dealing with impersonal topics" (Ales Bello, 2006, p.32). Like other phenomenological research methods, the heuristic investigation acknowledges subjectivity offering "formal resources for the researcher to look simultaneously at the object and at oneself" (Gomes, 2007, p.229), with the difference that its focus on oneself is sharper and more intense. The purpose of focusing on oneself is not to enclose oneself, but rather to access consciousness 
searching for the essence of the phenomenon, taking one's intentionality into account.

The present paper presents the heuristic method developed by Clark Moustakas throughout his academic life, describing the six phases that guide the pathway of this investigation and illustrating these phases using an example of a heuristic investigation on the experience of singing conducted in Brazil (Brisola, 2000). A brief discussion of the implications of this method in the contemporary field of research in psychology is also presented.

\section{Heuristic research}

Heuristic research was developed by the American psychologist, professor, researcher, and writer, Clark Moustakas (1923-2012), who worked alongside Carl Rogers and Abraham Maslow and was highly respected by fellow scientists (Maciel, 2004). Moustakas was an active participant of the Humanistic Movement in the 1960's, the birth of the Association for Humanistic Psychology, and founder of the Journal for Humanistic Psychology. He became well known for his contribution to the teaching of Clinical Humanistic Psychology, being one of the founders of the Center for Humanistic Studies (CHS) in Michigan (currently called the Michigan School of Professional Psychology). He published forty books and innumerous articles in the areas of clinical psychology, philosophy, and education and developed several investigations in human science (Moustakas, 1992, 1994a, 1994b, 2002).

His theoretical hypothesis and clinical studies contributed to the development of Play Therapy by being the pioneer of this work in the 1940's and 1950's (Blau et al., 2013; Moustakas, 1953).

His personal experience with his young daughter, who went through a process of recovery from a serious illness, led him to develop a new method of research and motivated him to write important books on the theme of "loneliness": Loneliness (Moustakas, 1961), Loneliness and Love
(Moustakas, 1972), and The Touch of Loneliness (Moustakas, 1975). Thirty years after his first publication, he wrote the book Heuristic Research: design, methodology, and applications (Moustakas, 1990b), in which he clearly and concisely describes the concepts, processes, and phases of the heuristic investigation. He also establishes guidelines and presents examples of research projects.

Moustakas (1990b, p.7) acknowledges that the development of the heuristic method was inspired and influenced by many scholars, mostly fellow humanistic psychologists. He mentions the research, theory, and concepts of Carl R. Rogers; the investigation on self-actualized people by Abraham Maslow; the emphasis given by Paul Bridgman on personal and subjective knowledge as an essential part of objectivity; the concepts of I-Thou, mutuality, mystery, and self-disclosure presented by Martin Buber and Sydney Jourard; the concepts of tacit dimension, indwelling, intuition, and validity in qualitative research introduced by Michael Polanyi; the understanding of the symbolic growth experience, related to identity and selfhood, a concept developed by Willard Frick; the concept of focusing introduced by Eugene Gendlin; and other important concepts and studies conducted by other authors such as Maureen O'Hara, Phillip Barrineau, and Jerald Bozarth. Moustakas also acknowledges that his theory and research method were influenced and molded by the writings of Sören Kierkegaard, Edmund Husserl, and Gordon Allport.

This list of authors characterizes the birth of the heuristic method in terms of humanistic discussions in a context in which psychologists and researchers questioned the standards of scientificity of their time and suggested an approach focused on subjective elements. Moustakas' method of research in psycology was developed based on the humanistic discussions that arose from acknowledgement and confidence in the human potential openness and respect, focusing on the individual's experience. The influence of these authors is evident in Moustakas' choice of vocabulary, concepts, and the research process he developed. 
Moustakas explains that the choice of the word "heuristic" - which derives from the Greek word heuriskein (discover, find) -, came from his search for "a word that would meaningfully encompass the processes that I believed to be essential in investigations of human experience" (Moustakas, 1990b, p.9). He believed that this word means an open-minded attitude towards discovery during the entire study. The word "heuristic" is usually used to refer to a trial-and-error way of solving problems. In psychology it is a way for solving problems quickly, taking short cuts. The noun Heuristic (n.d.), according to the Merriam-Webster Encyclopedia, is also commonly used in computer science, artificial intelligence, and mathematical optimization.

Moustakas' (Douglass \& Moustakas, 1985) heuristic research aims at the search for the discovery of "meanings and essence in significant human experiences" (p.40), focusing more on the process than on the results. In the search to understand the nature of a phenomenon, the researcher is invited to be an instrument through self-reflection and self-discovery. Self-discovery, selfdialog, and self-investigation are an integral part of the research process to uncover a phenomenon. The researcher becomes involved with the research in such a way as to perceive and understand it in a new way. When investigating, for example, the meaning of enthusiasm, it must become one's companion, a constant presence in one's thoughts, relationships, and reflections.

"The greatest contribution of the heuristic method is the intrinsic participation of the researcher in the research per se, i.e., the effective incorporation of the researcher subjectivity when undertaking the research" (Holanda, 2006, p.368). Such incorporation is evident in the entire process: the researcher continues extremely present during the entire process of investigation, conducts an investigation of oneself, explores one's own experience as well as the experience of others, reads, hears, and experiences the phenomenon. The encounter with others occurs; however, the focus is not on exploring rather on exploring one's own experience of this phenomenon when interacting with others.

For a beginner researcher, who is unaccustomed to including oneself in the investigation, focusing on one's own subjectivity may seem, initially, "unscientific". However, when looking at Moustakas' proposal attentively, despite the focus put on the person and creativity of the researcher, the purpose of maintaining scientificity and coherence can be clearly seen will become clear. It is, at the same time, a passionate and rigorous search for "knowledge that illuminates human problems related to the essence and meaning experienced" (Maciel, 2004, p.174) and a constant search for an authentic and precise description of a phenomenon.

The process of heuristic research has six phases (Douglass \& Moustakas, 1985; Moustakas, 1990b): initial engagement, immersion, incubation, illumination, explication, and creative synthesis.

Describing the six phases that guide the pathway of this investigation and illustrating these phases using an example of a heuristic investigation on the experience of singing.

\section{The experience of singing: An example of heuristic investigation}

We came in contact with the heuristic method for the first time in 1999, while searching for a suitable method to investigate the experience of singing, when we came across Stubbs' dissertation (1992): Individual experiencing in person-centered community workshops: a cross-cultural study. The method seemed appropriate for achieving the objectives proposed in the present study, and thus we decided to carry out a heuristic investigation. This unintentional encounter resulted in a master's thesis entitled Singing your troubles away: a heuristic study of the experience of singing (Brisola, 2000).

The objective of the study was to describe the elements present in the experience of singing from a perspective of mental health and clinical psychology. Six adults of both genders and of 
different ages, professions, education level, and interests were interviewed about important singing experiences they had had. The interviews were analyzed following Moustakas' (1990b) model and consisted of depictions of the singing experiences of each participant and of the group as a whole. In addition, two exemplary portraits of the participants that were thought to best represent the experiences of the group were developed, and, finally, a creative synthesis was written (Brisola, 2000).

The theme "singing" was chosen because of the personal interest of one of the authors her life as a singer, a choir member, a voice teacher, and also as a psychologist. Other influencing factors were remarks made by her students and her questions about her personal singing experiences and that enticed her curiosity about the phenomenon of singing as a human activity from a psychological point of view. Choosing the theme is the first phase of a heuristic research design, called Initial Engagement. Moustakas believes that the first impulse must be profoundly rooted in the researcher's life (Kenny, 2012), one that is motivated by a strong desire to know the phenomenon to find an issue of personal significance that begins, preferably, with a personal experience. "The awakening of such a question comes through an inward clearing and an intentional readiness and determination to discover a fundamental truth regarding the meaning and essence of one's own experience and that of others" (Moustakas, 2001, p.265). This personal disposition is fundamental to maintain the researcher's interest during the entire process of investigation. Without it, one loses the propelling motor of discovery.

Once the theme was determined, the researcher began to "live" it, paying close attention to everything related to singing, including her personal experience, comments made by her students, her personal observations of formal and informal presentations of singing, poetry, music, films, as well as conversations with friends, family, and strangers. Consequently, the researcher began a process of Immersion into the theme. Everything became a possible link to the chosen theme: interactions, contact with nature, places, literature, professional life; everything offered possibilities of understanding the theme.

"The immersion process enables the researcher to come to be on intimate terms with the questions - to live it and grow in knowledge and understanding of it" (Moustakas, 1990b, p.28). This also happens through self-dialog, "conversations" with the phenomenon, examining one's own experience and the experience as a whole "recognizing the place and unity of intellect, emotion, and spirit" (Moustakas, 1990b, p.16).

After a period of being immersed in the theme, the researcher then stepped back, purposefully. After having fulfilled the academic formalities of the project, she intentionally spent approximately 2 months away from the study, a period that coincided with a family trip abroad. This characterizes the third phase described by Moustakas as Incubation, in which the researcher takes a rest from the theme, steps back from immersion, and no longer focuses on it. The reason for this is to increase the tacit dimension. Tacit knowledge is one of the main concepts of this methodology, borrowed from Polanyi (1966). It can be described as the knowledge we have, but we do not know we have. Its importance in the heuristic process is that it precedes intuition and points the researcher in the direction of new meanings. Intuition creates a bridge between inherent implicit knowledge and the explicitly observable and describable knowledge. According to Douglass and Moustakas (1985), if tacit knowledge and intuition are not acknowledged, the potential for discovery and comprehension is reduced. In other words, during the incubation period, the researcher temporarily diverts the focus away from the study to avoid compromising the quality of comprehension (Maciel, 2004).

Then, after a period of withdrawal, there came a natural, enthusiastic return to the investigation of singing. Ten interviews were conducted, from which six were selected for analysis. Transcriptions and personal notes were read and re-read resulting in Illumination, an "A-ha" moment in which the researcher, naturally, scribbled several diagrams, ideas, and images that came to her mind, related 
to her understanding of the phenomenon of singing. According to Moustakas, illumination occurs when there is receptivity to tacit knowledge and intuition. The researcher becomes "naturally" aware of qualities and themes inherent to the theme in question, without any deliberate effort. "Illumination opens the door to a new awareness, a modification of an old understanding, a synthesis of fragmented knowledge, or an altogether new discovery of something that has been present for some time yet beyond immediate awareness" (Moustakas, 1990b, p.30).

Subsequently, the researcher examined what was naturally revealed to her consciousness regarding the experience of singing. Moustakas called this process Explication. Little by little, through focusing, indwelling, self-searching, and selfdisclosure the singularity of each experience becomes clear. Throughout the entire process of explication, it is important that the researchers attend to their "awarenesses, feelings, thoughts, beliefs, and judgments as a prelude to the understanding that is derived from conversations and dialogues with others" (Moustakas, 1990b, p.31). The researcher analyses, starting from one's own experience, the nuances, tessiture, and elements of the phenomenon. This investigation leads to the representation of the essence of the experience, of the main components of the phenomenon investigated. Another important concept used by Moustakas is that of focusing, which "points to a significant idea relevant to personal growth insight, and change" (p.25), an inward attention that enables a profound understanding of something; it includes opening an interior space for essential thoughts and feelings that facilitate receptivity to sensations and perceptions that lead us to a better understanding of what really matters, putting aside the tangential. Indwelling is another important concept that includes "inward" attention, which leads to a fundamental insight characterized by a conscious and deliberate process but not necessarily linear or logical. "It follows clues wherever they appear; one dwells inside them and expands their meanings and associations until a fundamental
Studying the experience of singing, explication occurred while the researcher deepened her understanding about singing in her own consciousness through all previous experiences, encounters with participants, everyday experiences, and everything she had lived through, seen, and read until that moment and are related to singing. She created individual depictions for each of the six participants containing her comprehension of each participant's experience. A composite depiction of the experience of singing as a whole was also created, which she called chorus, and next, following Moustakas' suggestion, two exemplary portraits were developed based on two participants who best represented the participants' singing experience.

According to Moustakas (1990b), the individual depictions, composite depictions, and exemplary portraits must retain the language and examples presented by the participants; they must also include the themes and qualities of the experience.

Below are some excerpts to exemplify individual depictions:

Mario: Singing means "to put all emotion out, to let out the voice of your heart, as Milton Nascimento puts it; to try to spread joy to everybody, so they are united, singing, pouring out their emotions; and I, myself, when I'm in that exercise, I love it, I forget all tensions, forget all sadness. I let go..." (Brisola, 2000, p.78).

Vitória: "Well, this is how it was, I remember I sang to my son, the first time I held him... I didn't even think, it just seemed normal, a natural instinct... I picked him up and started to sing... I remember when I held him, felt my face touch him, it was meaningful, because it seemed like he liked hearing me. He became calm, quiet, so I felt close to him" (p.62).

Sandra: Singing has served as a link to other people, a feeling of belonging to a group "... in that moment everyone felt united, too, and that emotion flowed through everyone" (p.66). 
And two excerpts of exemplary portraits:

Sandra: When she sings, memories and images related to people and moments she experienced become present with the strength of the emotions lived in that situation, "I really miss the people that are far away, sadness sweeps over me, nostalgia of the things I lived during that moment with that song, like a little movie - that's what happens to me -, certain songs fill me with memories" (p.86).

Nadine: When singing, Nadine dives in to the meaning of the words in her life, words become her life: "When you're singing something that you are living... it drowns you with emotion because you sing and think about your life, too. You tie everything together" (p.84).

At the end of the investigation, a Creative Synthesis was created. This is the final step of the heuristic method described by Moustakas. It is a creation that emerges from the researcher's familiarity with the phenomenon and grows from tacit and intuitive dimensions. Moustakas (1990b) encourages the researcher to "move beyond any confined or constricted attention to the data itself and permit an inward life on the question to grow, in such a way that a comprehensive expression of the essences of the phenomenon investigated is realized" (p.32). This can be translated into a creative production such as a poem, story or drawing. In this study addressing singing, the synthesis blossomed into the form of a poem. Below are some fragments transcribed from the Creative Synthesis:

Do you want to love someone?

sing to them.

Do you want to say something inexpressible? Sing.

Do you want to be heard?

Sing.

Do you wish to know yourself?

Sing...

Are you sad?

Sing.
Are you happy?

Sing...

Do you wish to switch off the problems of the world?

Sing...

Do you want to remember the past?

Sing...

Do you wish to renew your values, your faith?

Sing.

Do you want to take care of you health?

Sing.

Sing at home.

Sing in the streets.

Sing in the car.

sing alone.

Sing with friends.

Sing for God.

Sing for yourself.

And hear your heart.

Hear your body.

Hear your desires.

Hear your thoughts.

Hear your memories.

Hear your sound.

You don't wish to sing?

Then don't sing. But your song is inside you, looking for space, wanting to participate (Brisola, 2000, p.86).

These are, succinctly, the six phases of the heuristic research described by Moustakas (1990b). They guide the process of investigation, always acknowledging the researcher's subjective experience, tacit knowing, intuition, focusing, indwelling, self-revelation, self-dialog, and internal frame of reference. This approach is a persistent, methodical, and disciplined search aimed to deepen the knowledge of the studied phenomenon. The process occurs within the investigators' themselves. They become the "first to try out theses, tests, theories, and interventions" (Maciel, 2004, p.102). That is how, in Moustakas' words (1990b), "the process of discovery leads investigators to new images and meanings regarding human phenomena, 
but also to realizations relevant to their own experiences and lives" (p.9).

In addition to these six phases, Moustakas also provides researchers with an Outline Guide of Procedures for Analysis of Data, permeated by the same precepts described above.

\section{Final Considerations}

The heuristic investigation is a phenomenological way of researching distinguished by the explicit recognition of the researcher's involvement with a phenomenon to the extent that it becomes the main focus of the investigation. It includes the experience of the researcher in an active and constant manner during the entire investigation without, however, "falling into subjectivism". The researcher's self is present throughout the study, from the identification of the question to the conclusion of the study, as illustrated above. The process of dis-covering the phenomenon is personal (How does it affect me and how do / see it?), creative (giving room to new ideas), and filled with selfdiscovery (so, this is how it affects me!). The researcher becomes more self-aware and grows in self-knowledge. Therefore, one does not simply complete another research project, but goes through a transforming experience.

A heuristic investigation places great responsibility on the researcher. Moustakas makes it clear that it is a challenge to creativity and authenticity as well as to reflection, when one tries to understand the most obvious and subtle elements of the meanings and essences of the studied phenomenon. A researcher must question oneself constantly, verifying whether one's explanations are complete and whether one's own experience and the participant's experiences were considered. In order to do this, one must be emotionally available and willing to meet the unexpected and rethink what one takes for granted.

This research method requires, therefore, a high degree of rigor, integrity, and "wholeness" from the researcher - who is also an instrument -, losing contact with subjectivity. This is a balance the researcher must seek, an effort to remain, according to Carl Rogers, a scientist and also a person, a human being, during the entire process. This is achievable when one enjoys each experience thoroughly maintaining close connection with oneself in each situation.

During the investigation, there are situations to register and explore meanings, to search for understanding and pave pathways. Nonetheless, before registering or explaining something, the researcher must experience it. This is what Moustakas describes as "being with the data". This is what distinguishes this method. It is expected that the researcher focuses on his or her own experience, to investigate, explore, and include this experience in the research process. It includes delving into the personal (subjective) field and then a systematic attention to this personal field.

To be concentrated on one's own experience does not mean that openness to others is not present. On the contrary, the researcher does open up to the experience of others, seeking to deeply understand their experience while suspending one's own judgments. This contact has an effect on the researchers by illuminating one's own internal frame of reference and pointing to influences on one's actions and choices. The relationship with others becomes an opportunity to explore the phenomenon arising from the impact it had on the researcher. The researcher focuses on one's attention and dives into a deep understanding of the experience, becoming receptive to all of its aspects. Moreover, openness to one's own experience influences the participant, who also opens him- or herself. In this relationship, the willingness to be open contributes not only to the deepening of the experience but also of the understanding of the phenomenon.

Moustakas' proposal highlights the integration of the researcher with his or her work, recognizing that the search for information is also a search for personal integration and realization. Incorporating experiences, intuitions, and tacit knowledge into the research, there is openness for the researcher to become fully present. Including oneself as an 
instrument in the research process can be a pathway to personal integration.

Emphasis on the researcher's experience is not a common practice. In heuristic research, it confers strength and poses challenges to the method. The adavantages and limitation of this method reside in its principal characteristic: emphasizing the researcher's self-investigation. One may recognize its importance due to its results: richness of the phenomenon's description and meanings, preservation of the delicate nuances of human lived experiences, interactions, and encounters. On the other hand, the challenge remains in letting experience and subjectivity truly be the instruments to comprehend a phenomenon. This requires effort on the part of the researcher, who must trust in oneself and others, perceive the occurrence of discovery, and express oneself clearly, authentically, and fully. Openness must therefore be present in the scientific report demonstrated by the researcher's transparency in writing the description.

Discovery (heuriskein) is a central concept in this method. According to Carl Rogers, discovery means openness to experiences, trust in one's self-awareness and comprehension, personal evaluation, and willingness to engage in a process that is based on one's self.

Validity, as highlighted by Moustakas, is closely related to the meanings. One must ask: does the study describe, in a vivid precise way, the meanings and essence of the studied phenomenon? This analysis can only be completed by the researcher during the investigation, while one reflects, explores, checks, and reads and rereads the interviews, descriptions and synthesis. In some cases, the researcher talks to the participants again, sharing the descriptions and requesting an evaluation of the material's precision.

In heuristic research, like in other phenomenological studies, there is a search for the continuity of the phenomenon, a deepening of the meanings in order to find the common elements of a human experience, the "universality" of the phenomenon. This type of research requires one to deepen the contact with both oneself and the participants enabling one to dive into the experience and come to conclusions about the phenomenon. This process allows one to understand other people who went through the same or similar circumstances. Therefore, it acknowledges the continuity of the phenomenon and not its generalization starting from a hypothesis.

Like in other phenomenological investigations, in the heuristic study, the choice of participants is of fundamental importance. The participants are, in general, few in number (Moustakas suggests 10 to 15 participants) and must, necessarily, have a personal experience of the phenomenon in question and be willing to engage in dialogue with the researcher in a way that permits an encounter between them, not simply a collection of data or exchange of information.

One of the typical features of heuristic research is to include in the immersion phase all of the researcher's experiences that are related to the theme through one's daily life and work, literature, artistic, or musical expressions, observations, films, etc. Other qualitative methods may also include these means, but they consider them a form of data collection or application of an instrument. In heuristic studies, the emphasis falls on the impact of these expressions on the researcher seeking intimacy with the phenomenon. As a result of the lived experience, the researcher grows as a person and deepens its understanding. In the end, these experiences bring richness to the description of the human phenomenon ensuring its continuity and universality.

We had a brief but important and fruitful contact with heuristic research, which allowed for reflection and questioning inspiring further research. Although in our current studies we do not follow the steps of the heuristic investigation as proposed by Moustakas; we incorporate the experience of the researcher in the process in a more radical way, especially in the elaboration of narratives based on dialogical encounters between the researcher and participants. For more information on these studies, see Campos and Cury (2009), Mozena and Cury (2010), Perches and Cury (2013). 


\section{Contributors}

All authors contributed to the conception and design of the study, data analysis and final draft of the article.

\section{References}

Ales Bello, A. (2006). Fenomenologia e ciências humanas: implicações éticas. Memorandum, 11, 28-34.

Amatuzzi, M. M. (2010). Rogers: ética humanista e psicoterapia. Campinas: Alinea.

Batista, T. C., \& Maciel, J. C. (2011). Um estudo sobre o olhar na construção do campo de pesquisa. Trabalho apresentado no II Congresso Sul Brasileiro de Fenomenologia \& II Congresso Paranaense de Estudos Fenomenológicos, Curitiba.

Blau, D., Bach, L., Scott, M., \& Rubin, S. (2013). Clarck Moustakas (1923-2012): Scholar, teacher, colleague and friend. The Humanistic Psychologist, 41(1), 97-99. http://dx.doi.org/10.1080/08873267.2013.752695

Brisola, E. B. V. (2000). Quem canta os males espanta: um estudo heurístico da vivência de cantar (Dissertação de mestrado não-publicada). Pontifícia Universidade Católica de Campinas.

Brisola, E. B. V. (2014). Fostering dignity through singing: Contributions from a heuristic research. Work presented in the $7^{\text {th }}$ Annual Conference of Society for Humanistic Psychology, Palo Alto, CA.

Brisola, E. B. V., \& Cury, V. E. (2013). Quando a experiência do pesquisador torna-se o elemento essencial na investigação de um fenômeno: um exemplo de pesquisa heurística. Trabalho apresentado no II Congresso Sul Brasileiro de Fenomenologia \& II Congresso Paranaense de Estudos Fenomenológicos, Curitiba.

Campos, A. P. S., \& Cury, V. E. (2009). Atenção psicológica clínica: encontros terapêuticos com crianças em uma creche. Paidéia, 19(42), 115-121.

Douglass, B., \& Moustakas, C. (1985). Heuristic inquiry: The internal search to know. Journal of Phenomenological Psychology, 25(3), 39-54.

Gomes, W. B. (2007). Distinção entre procedimentos técnico e lógico na análise fenomenológica. Revista da Abordagem Gestáltica, 13(2), 228-240.

Heuristic. (n.d.). In Merriam-Webster's online dictionary. Retrieved May 2, 2014, from http://www.merriamwebster.com/dictionary/heuristic

Hiles, D. (2001). Heuristic inquiry and transpersonal research. Paper presented to CCPE, London. Retrieved October 21, 2014, from http://psy.dmu.ac.uk/drhiles/ Hlpaper.htm
Holanda, A. (2006). Questões sobre pesquisa qualitativa e pesquisa fenomenológica. Análise Psicológica, 3(XXIV), 363-372.

Kenny, G. (2012). An introduction to Moustakas's heuristic method. Nurse Researcher, 19(3), 6-11.

Maciel, J. C. (2004). A ciência psicológica em primeira pessoa: o sentido do método heurístico de Clark Moustakas para a pesquisa em Psicologia (Tese de doutorado não-publicada). Pontifícia Universidade Católica de Campinas.

Maciel, J. C. (2011). Pesquisa heurística e psicologia social: proposição e perspectivas. Trabalho apresentado no $16^{\circ}$ Encontro Nacional de Psicologia Social da ABRAPSO, Recife.

Madill, A., \& Gough, B. (2008). Qualitative research and its place in psychological science. Psychological Methods, 13(3), 254-271. http://dx.doi.org/10.1037/a 0013220

Moustakas, C. (1953). Children in play therapy. New York: McGraw-Hill.

Moustakas, C. (1961). Loneliness. Englewood Cliffs: Prentice-Hall.

Moustakas, C. (1972). Loneliness and love. Englewood Cliffs: Prentice-Hall.

Moustakas, C. (1975). The touch of loneliness. Englewood Cliffs: Prentice-Hall.

Moustakas, C. (1981). Rythms, rituals and relationships. Detroit: Center for Humanistic Studies.

Moustakas, C. (1990a). Heuristic research: Design and methodology. Person-Centered Review, 5(2), 170-190.

Moustakas, C. (1990b). Heuristic research: Design, methodology, and applications. London: Sage.

Moustakas, C. (1992). Firebrand: The experience of being different. The Humanistic Psychologist, 20(2-3), 175-188.

Moustakas, C. (1994a). Phenomenological research methods. London: Sage.

Moustakas, C. (1994b). The I and thou of evidence: A fusion of opposites. The Humanistic Psychologist, 22(2), 238-240.

Moustakas, C. (1995). Being-in, being-for, being-with Lanham: Rowman \& Littlefield.

Moustakas, C. (2001). Heuristic research: Design and methodology. In K. J. Schneider, J. F. T. Bugental, \& J. F. Pierson (Eds.), The handbook of humanistic psychology: Leading edges in theory, research, and practice. London: Sage.

Moustakas, C. (2002). Solitude and communion. Association for the Integration of the Whole Person, 2(2), 15.

Mozena, H., \& Cury, V. E. (2010). Plantão psicológico em um serviço de assistência judiciária. Memorandum, 19, 65-78. 
Perches, T. H. P., \& Cury, V. E. (2013). Plantão psicológico em hospital geral e o processo de mudança psicológica. Psicologia: Teoria e Pesquisa, 29(3), 313-320.

Polanyi, M. (1966). The logic of tacit inference. Philosophy, 41(155), 1-18.

Rennie, D. (2012). Qualitative research as methodical hermeneutics. Psychological methods, 17(3), 385-398. http://dx.doi.org/10.1037/a0029250385

Sales, Y. N., Sousa, A. F., \& Cavalcante Junior, F. S. (2012). Ciência e pesquisa centradas na pessoa: três modelos e seus efeitos na condução da investigação acadêmica. Revista do NUFEN, 4(2), 99-112.

Santana, S. C., \& Maciel, J. C. (2011). Pesquisa heurística e clínica do social: um ensaio teórico-prático. Trabalho apresentado no II Congresso de Estudos Fenomenológicos do Paraná e II Congresso Sul Brasileiro de Fenomenologia, Curitiba.

Schneider, K. J., Bugental, J. F. T., \& Pierson, J. F. (2001). Handbook of humanistic psychology: Leading edges in theory, research, and practice. London: Sage.

Stubbs, J. P. (1992). Individual experiencing in personcentered community workshops: A cross-cultural study
(Doctoral dissertation unpublished). University of Georgia, Athens.

Vasconcelos, T. P. (2009). A atitude clínica no plantão psicológico: composição da fotografia experiencial do terapeuta-sherpa (Dissertação de mestrado não-publicada). Universidade de Fortaleza, Ceará.

Vian, O. (2008). Experiências vividas no planejamento de cursos instrumentais: percursos de transformação numa abordagem heurístico-fenomenológico-hermenêutica. Revista Brasileira de Linguística Aplicada, 8(2), 465-488.

Villar, A. S., \& Maciel, J. C. (2011). Sentido de reuniões de devolutiva no contexto da investigação científica. Trabalho apresentado no I Congresso de Estudos Fenomenológicos do Paraná e II Congresso Sul Brasileiro de Fenomenologia, Curitiba.

Received: June 25, 2014

Final version: December 5, 2014

Approved: March 31, 2015 
